\title{
APPLIED ASPECTS OF STUDY OF FINANCIAL LITERACY OF HOUSEHOLDS IN BULGARIA
}

\author{
Dancho Petrov ${ }^{1^{*}}$ and Evgeniya Tonkova ${ }^{2}$ \\ ${ }^{1}$ Assoc. Prof. Dr., University of Economics - Varna, Bulgaria, dpetrov@ue-varna.bg \\ ${ }^{2}$ Assoc. Prof. Dr., University of Economics - Varna, Bulgaria, tonkova@ue-varna.bg \\ ${ }^{*}$ Corresponding author
}

\begin{abstract}
The World Economic Forum identifies financial literacy as one of the six core competencies of the 21st century. The study of the level of financial literacy of households is provoked by the invasion of technological innovations in the financial markets, which increase the complexity of financial products. Financial literacy is determined by the subjective abilities of individuals to perform independent assessments and to make appropriate financial and investment decisions based on acquired knowledge and skills. The present study focuses on two main aspects that characterize financial literacy - lending and investing in financial markets. The study is conducted through an online survey among adults in Bulgaria. The results obtained can be used in improving the approaches to increased financial literacy of households through formal and non-formal education and self-education.
\end{abstract}

Keywords: Financial literacy, Households, Households indebtedness

\section{INTRODUCTION}

In the era of digitalization and deregulation of financial markets, the level of financial literacy of households is an issue that is becoming increasingly relevant and provokes the interest of researchers. The rising household indebtedness globally over the past decade has raised legitimate concerns about the financial stability of households and their ability to absorb shocks. The inevitable difficulties in servicing debts upon occurrence of events of risk can cause huge potential public costs. Factors of various kinds contribute to the "pumping up" of household indebtedness - record low market interest rates, loosening of credit standards, financial innovation, upward trends in housing prices and income growth (Djoudad, 2011). Households are at risk to varying degrees in their capacity as depositors, insurance beneficiaries, equity investors and bondholders. They are exposed to a multitude of financial risks of various kinds - market risk, inflation risk, investment and reinvestment risk, etc. (Santoso \& Sukada, 2009). There are various channels through which financial risk is "injected" into households (IMF, 2005). The improvement of risk management techniques by financial institutions and the aggressive offering of innovative and increasingly complex financial services facilitate the transfer of risk to customers. With the invasion of new technologies and the accelerated digitalization of the financial industry, consumers find themselves in a new, for a large proportion of them unfamiliar environment. The level of their financial literacy plays a crucial role in their faster adjustment and adaptation to this new environment. Increasing the financial literacy of households is becoming one of the most important factors for making adequate financial decisions and minimizing the risks in the management of family finances. The purpose of this paper is to study the level of financial literacy of households in Bulgaria in two main aspects - lending and investing in financial markets. The body of the text is structured 
Proceedings of INTCESS 2022- 9th International Conference on Education \& Education of Social Sciences 17-18 January 2022- Online Conference

into two sections - a literature review and an empirical study of the level of financial literacy of households in Bulgaria.

\section{LITERATURE REVIEW}

Rational decisions in borrowing financial resources require a sufficient level of financial literacy to prevent the accumulation of debt that exceeds the capacity of households to service it properly. The results of research conducted in the United States show that low levels of financial literacy are widespread and correlate with over-indebtedness (Lusardi \& Tufano, 2015; Gerardi et al., 2010). Wrong investment decisions are usually due to incorrect assessment of financial conditions due to insufficient level of financial literacy, overconfidence and lack of self-control. Gathergood (2014) finds that both lack of self-control and financial illiteracy are positively associated with non-payment of consumer credit in the UK, but according to him, the lack of self-control plays a more important role than financial literacy in explaining consumer overindebtedness. Anderloni \& Vandone (2010) highlight emotional factors, such as overconfidence, impulsivity in consumption attitudes, social comparison and myopia, which lead to "non-rational" borrowing choices. By their nature, behavioural factors such as overconfidence or poor self-control lead to wrong financial decisions due to inadequate understanding of the real cost of the loan or underestimation of the possible consequences of the occurrence of events of risk. We believe that the manifestation of such behaviour is caused by insufficient knowledge, skills and experience or, in other words, low level of financial literacy. The unsatisfactory level of financial literacy is, in our opinion, the main reason for the manifestation of unrealistic consumer expectations and leads to underestimation of the probability of suffering financial damage upon occurrence of adverse events. A similar view is shared by Bucks \& Pence (2008), who found that some borrowers with adjustable-rate mortgages tend to underestimate, are not aware of, or are not interested in how much the interest rate on their loans may change. However, Lusardi \& Tufano (2015) clarify that this may be due as much to unsatisfactory financial literacy of borrowers and underdeveloped skills of managing their finances as to the insufficient transparency of lenders' terms and conditions. According to Petrov et al. (2021) one of the most important missions of policymakers is to take initiatives on the one hand to increase the transparency of lending conditions and the real cost of borrowing and on the other hand to increase the financial culture of households in the EU.

Whether due to overconfidence or underestimation of the possibility of shock scenarios, households may be maintaining an insufficient savings reserve or excessive debt. Persson (2009) points to two main factors in the increase in indebtedness - financial deregulation, which has helped ease credit restrictions and the reduction of interest rates in nominal and real terms. In this context, the record low interest rates we are witnessing today can be seen as a lasting and sustainable trend and financing decisions may be based entirely on such view, while ignoring other important factors. Such a development of consumer behaviour can be further catalyzed by changes in the risk management of credit institutions, which in long periods of low interest rates usually leads to a loosening of credit conditions for new loans. Dynan and Kohn (2007) call this process "credit democratization" and link it to the easier access to credit, which they estimate "contributes" with about $1 / 7$ to the increase in indebtedness. The focus of their study is on financial innovation and securitization of mortgage loans. It was precisely financial innovation that facilitated the access to credit. In recent decades, banks have begun to provide housing mortgage loans on more favourable terms, such as longer repayment periods and more generous debt-to-value ratios. At the same time, financial intermediaries offer new and increasingly complex financial products. Driven by their desire for growing profits from commissions, providers of such products adopt aggressive approaches in their offering, emphasizing the opportunities for achieving high returns and neglecting the investment risk. There are also tempting offers to finance such investment opportunities at relatively low interest rates. This creates additional confusion among clients who blindly put their trust in unscrupulous consultants or rely on their own intuition, which is not backed by the necessary knowledge and skills. Pressed by the "time" factor and the threat of missing out on a "winning" opportunity, people often ignore the risk and make imprudent investment decisions.

Deregulation of financial markets has historically changed the rules of the game (Gerardi, Rosen \& Willen, 2010). Financial deregulation combined with credit market imperfections is among the factors that can push households to excessive borrowing (Finocchiaro et al., 2016; Lorenzoni, 2008; Bianchi and Mendoza, 2011). The easing of credit conditions leads to the accumulation of debt by households that have limited financial resources or have not had access to credit due to strict credit standards and limits. Credit limits are determined not only by household income, but also by the market value of collateral. During an economic boom, collateral values can skyrocket, creating the preconditions for a price bubble. The part of the investors, who are not able to adequately assess the situation and have unrealistic expectations for the growth of asset prices, incur excessive debt above the rational or optimal levels in a boom phase. In the 
financial markets, such unwise credit behaviour does not go unpunished. Overconfidence and misjudgments can be costly to borrowers. As is well known, in the event of a financial collapse, urgent sales of assets lead to drastic declines in their prices. The ability of over-indebted households to service their loans is shrinking. They would not be able to alleviate their financial position by refinancing their debt due to the declining value of collateral. In such situations, the sale of assets is also not a solution to debt problems, as it inevitably leads to losses. The consequence is a vicious circle from which it is difficult to find a way out. The results of research conducted during the global financial crisis in the United States confirm the above opinion. According to Geanakoplos (2010), the rise in housing prices in the United States just before the crisis was mainly due to credit expansion, and the simultaneous interaction of two cycles of leverage - in the financial and housing sectors - has catalyzed the ongoing processes. High leverage households entering the housing market en masse further fuel the upward trend in real estate prices. The sharp drop in housing prices during the crisis has made lenders much more cautious, making the refinancing through new loans difficult, and for many households even impossible.

Changes in market interest rates have a direct impact on the ability of households to service their debts. This, of course, applies to a much greater extent to loans with variable interest rates, such as those prevailing in retail credit markets. However, not all borrowers are able to perceive the causal links in the changing market interest rates in their nominal and real terms. One of the starkest examples of lack of financial literacy is the so-called "money illusion" effect, which occurs in individuals who do not understand the difference between nominal and real values (Finocchiaro et al., 2011). According to Brunnermeier and Julliard (2008), in resolving the dilemma between renting and buying a home, there is often a confusion between real and nominal interest rates, and decision-making in such cases can become subject to the illusion of money. Wrong estimates lead to underestimation of future mortgage payments and cause housing prices to rise during periods of relatively low inflation. This is due to the discrepancy in the understanding of real interest rates between financially literate investors and those who are subject to illusions, which is reflected in higher demand for loans and can push the prices of collateral (Piazzesi \& Schneider, 2007). This scenario operates in periods of both low and high inflation. With low inflation rates, "illusion"-prone investors usually confuse low nominal rates with low real rates and prefer to buy a home precisely at such times. In periods of high inflation, they are replaced by smarter investors in the market. Such investors understand correctly that in such periods the real interest rates fall, and that such times are good for investment.

A large proportion of households that do not show the necessary flexibility in managing their debts and find it difficult to adapt to changes in the market environment have difficulty servicing their debts during an economic crisis. In this respect, the current crisis caused by the global Covid-19 pandemic puts many unknowns in the formula for successful family finance management. Undoubtedly, this crisis is different from all the others, it follows a very different scenario and is not subject to management through any known models for financial risk assessment (Bilyk, et al., 2020). Accordingly, the question of how the shock of the pandemic will affect the ability of households to service properly their debts is placed on the agenda. This problem affects mainly such households that have had the recklessness to accumulate solid debts and consequently suffer a significant decline in their current income. This poses many challenges not only to the management of household finances, but also to risk management in financial institutions, the activities of regulatory authorities and the socio-economic policy of the state.

\section{RESULTS OF A SURVEY ON THE FINANCIAL LITERACY OF BULGARIAN HOUSEHOLDS}

For the purposes of the study of the level of financial literacy of households in Bulgaria, an online survey was conducted within a period of time $3 / 10-17 / 112021.91$ respondents took part in the survey, which consists of 12 questions, structured in two sections. The first section contains questions that assess the respondents' knowledge of making loan decisions, and the second section focuses on investment decisions. Financial literacy is undoubtedly a phenomenon with a much broader dimension and can be assessed with knowledge in other areas of financial science such as insurance and taxation. Limiting research to only these two aspects, namely lending and investing is based on the understanding that they could best outline financial literacy as a factor influencing individuals' financial decisions and the level of household indebtedness.

The first question in the survey aims to determine which of the three indicators the respondents consider to be the most important when comparing different offers for consumer loans. The majority of respondents $(63.3 \%)$ correctly pointed out the summary indicator for the real price of the loan "Annual percentage rate of charge (APRC)" as the most important benchmark. Lower interest rate and lower monthly installments, in spite of a higher APRC are the leading criteria for the rest of the respondents. These results show that slightly more than a third of all respondents find it difficult to correctly determine the real price of a loan. 
Another issue is related to determining the real price of loans by asking a question with specific parameters: "What is the real (effective) rate of a bank loan in the amount of BGN 10,000; one-year term; 10\% nominal annual interest payable all at once on maturity (i.e. after one year); no other fees and commissions; requirement for $15 \%$ no-interest-bearing compensatory balance on the current account of the debtor in the amount of BGN 1,500?" Three alternatives are suggested for the answer to this question: lower than the nominal interest rate (10\%); equal to the nominal interest rate and higher than the nominal interest rate. This question was intended to test the ability of respondents to find their way around the problem without even having to make accurate calculations. Only $38.2 \%$ answered this question correctly.

A question that caused confusion among respondents reads "How would you like to pay your loan installments if the goal is to pay less interest" (Fig. 1). The most common answer is equal monthly installments (39.6\%), which could be accounted for by the usual practice of repayment plans with monthly interest payment most frequently applied by banks. Only $37.4 \%$ of respondents managed to realize that the shortest period of instalments payment is associated with the lowest amount of interest due.

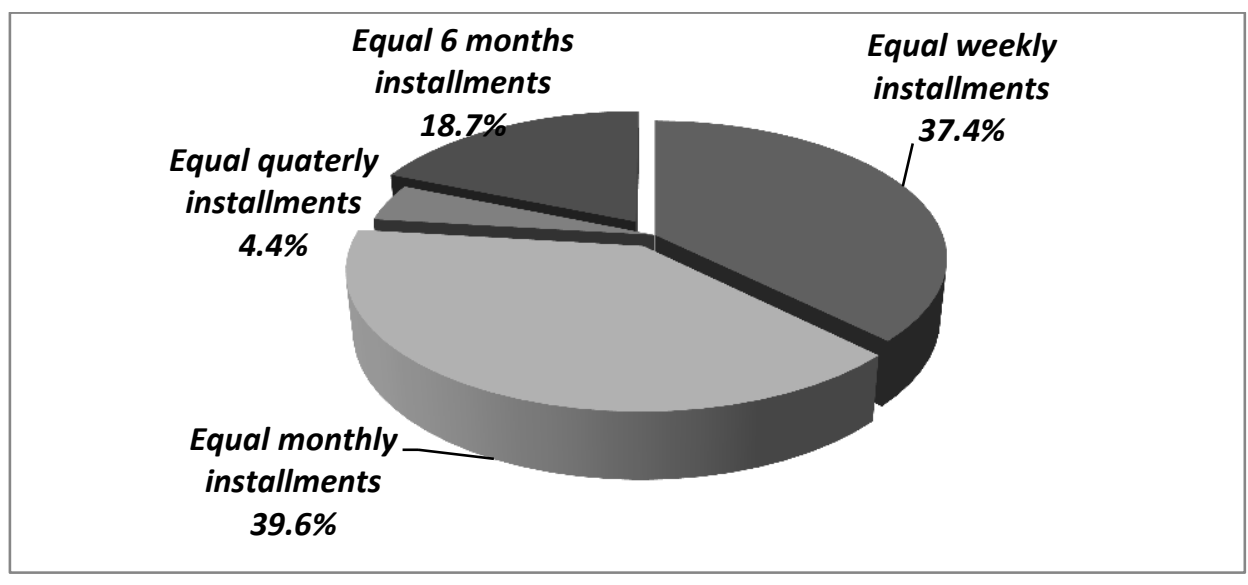

Fig. 1. Distribution of answers to the question „How would you like to pay your loan installments if the goal is to pay less interest?"

The digitalization of financial services and consumer preferences for non-cash payments leads to an increasing use of card services. Therefore, it is not surprising that most respondents show very accurate awareness of the question: "When withdrawing cash from an ATM, which card do you prefer to use: debit, credit or either?" To this question, $92.2 \%$ of respondents answered: "debit card". The increasingly frequent use of credit cards and the gained experience with card payments account for the respondents' answers.

The second section, which assesses the financial literacy of respondents in terms of investing in financial markets, includes issues of varying difficulty. Some of the questions aim to determine whether the respondents have sufficient knowledge of the nature of investment, basic terminology and basic financial instruments. Other issues require more in-depth knowledge of the relationships and dependencies between different factors.

Two of the questions in the survey test the respondents' knowledge of the nature and specifics of the traditional financial instruments: stocks and bonds. The results show that a large part of respondents find it difficult to determine the status of bonds as a debt instrument (Fig. 2). Approximately half of them (48.9\%) give a correct answer to the respective question.

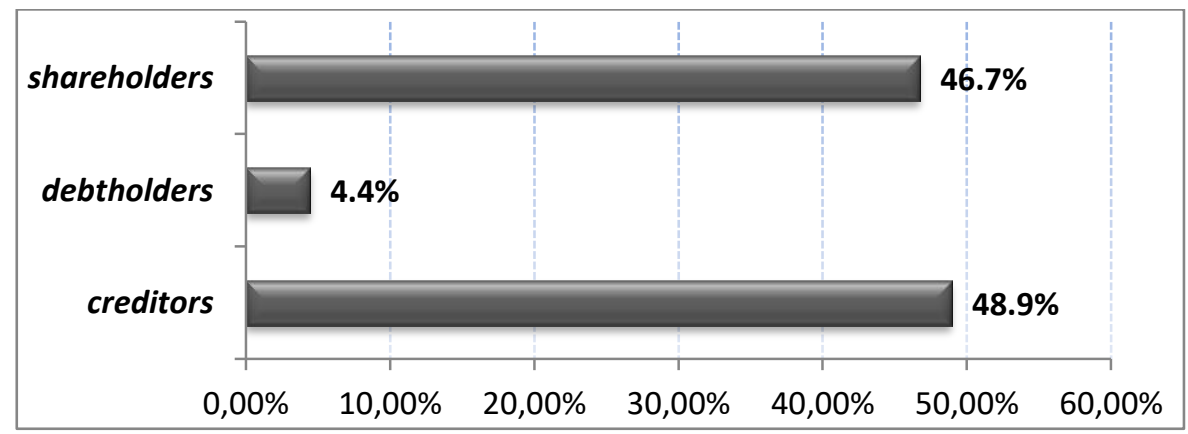

Fig. 2. Distribution of answers to the question „What is the status of bondholders in a company?" 
Indicative of the insufficient knowledge of the respondents is that only $33.3 \%$ gave a correct answer to the undoubtedly provocative question: "If you bought a share for BGN 100 and sold it for BGN 120 two years later, what was your dividend?" (Fig. 3) The majority of respondents apparently confuse dividends with capital gain when selling shares.

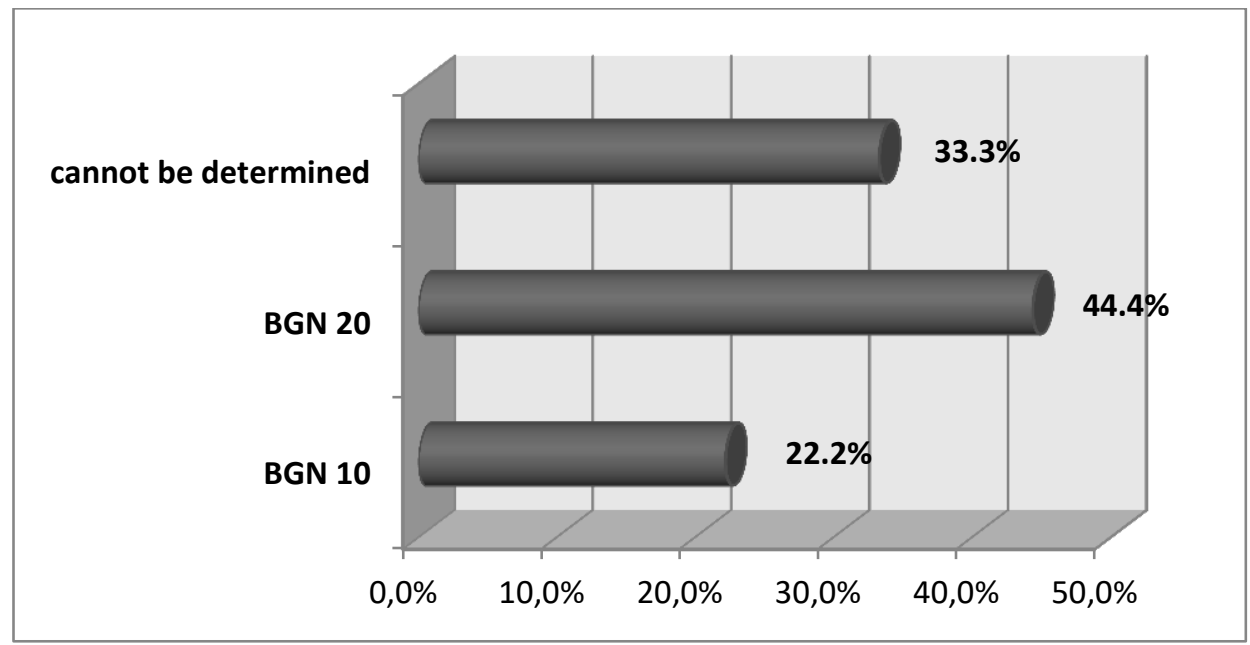

Fig. 3. Distribution of answers to the question ,If you bought a share for BGN 100 and sold it for BGN 120 two years later, what was your dividend?"

The purpose of the next series of questions is to check whether the respondents are familiar with the compounding interest rate rule. Only $42.2 \%$ understand the principle of forming the effective interest rate, while nearly half of respondents $(47.8 \%)$ choose the most irrelevant alternative in this case (Fig.4).

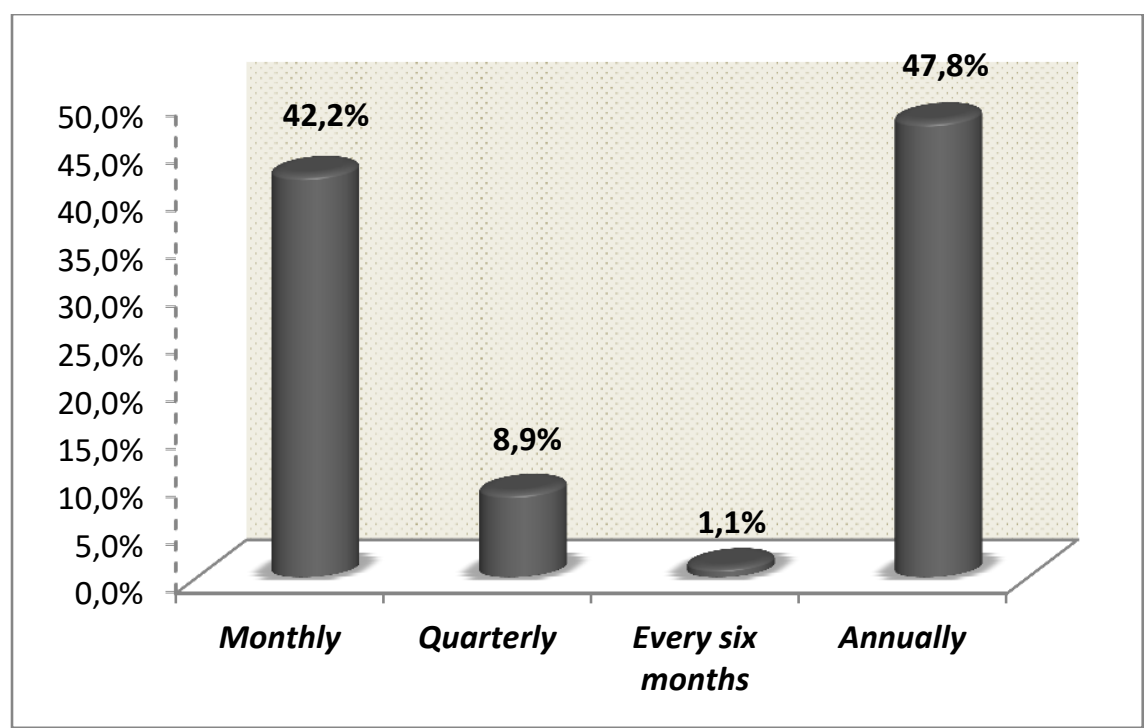

Fig. 4. Distribution of answers to the question "If we invest BGN 10,000 at a $10 \%$ annual return for 1 year, we will get the highest return if we receive interest payments monthly; quarterly; every six months or annually?"

The following question is analogous to the previous one: "You are offered two investment opportunities: the first one provides a $6 \%$ annual yield, while the second one gives you a $0.5 \%$ monthly yield. Which of the two do you prefer? Exactly half of the respondents (50\%) correctly assessed the realization of a higher effective interest rate when choosing the monthly interest.

To the question: "If you invest BGN 5,000 at 10\% annual return for a period of 3 years, what amount will you receive" an even higher percentage of respondents (55.1\%) compared to the previous two questions marked the correct answer.

Two of the questions require respondents to assess the relationships and dependencies that are manifested in financial markets trading. The first one tests respondents' knowledge of the relationship between changes in interest rates and the market value of financial assets (Fig.5). Over half of respondents (53.3\%) chose the 
correct answer.

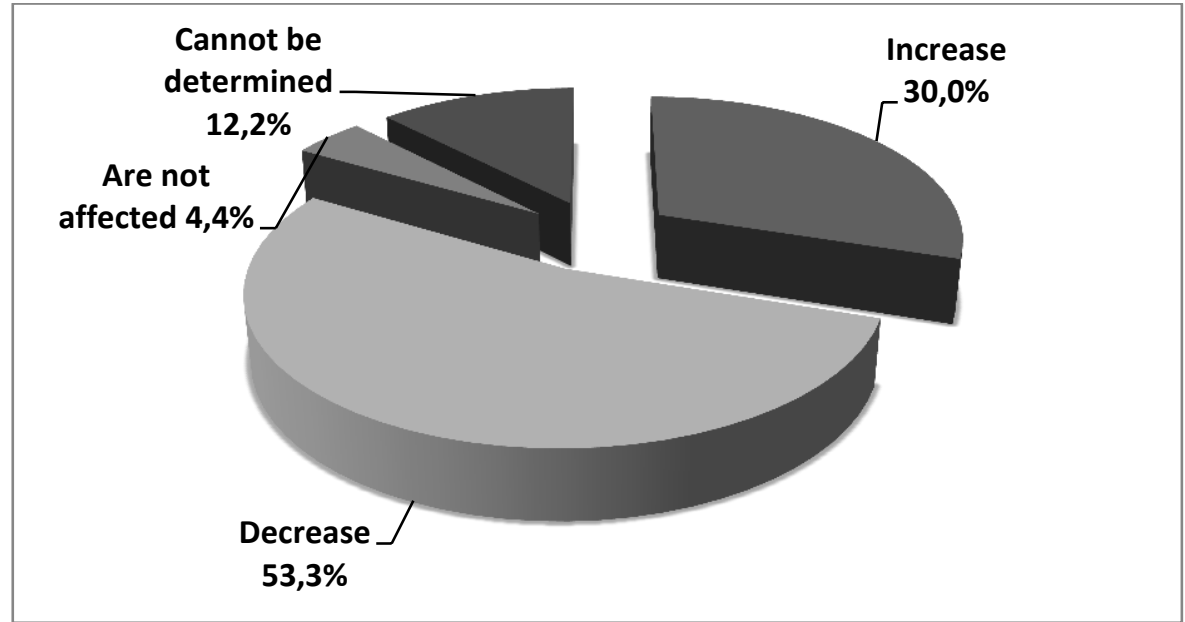

Fig. 5. Distribution of answers to the question "When market interest rates rise, what happens to the prices of most financial assets?"

It is not surprising that to the next question: "What is the relationship between investment risk and the expected return on financial investment the percentage of correct answers is almost the same as in the previous question (54.4\%). This question tests the knowledge of the "risk-return" relationship of financial assets.

It can be summarized from the conducted research that two critical areas are identified in the level of financial literacy of respondents. The first of them is that the most common difficulties of respondents are related to determining the real price of the offers for taking a loan. A relatively small share of respondents take into account the fact that when making more frequent payments, the loan principal is depreciated faster and this leads to lower interest costs. The second critical area is the unsatisfactory knowledge of the characteristics and specifics of the classic equity and debt financial instruments: stocks and bonds.

\section{CONCLUSION}

Financial literacy is a factor that influences the financial decisions of individuals. Irrational credit behaviour of borrowers, due to a low level of financial literacy, leads to a long-term deterioration of their financial condition and increased credit risk from excessive indebtedness. The unbearable debt burden of households, in turn, has a negative impact on the state's social policy and puts strong pressure on public spending. This problem is particularly acute in a period of crisis caused by the global Covid-19 pandemic. Therefore, increasing the financial literacy of households should become a priority of the socio-economic policy in Bulgaria. Increasing the financial literacy is not a static process. It requires the development of a long-term program with the joint efforts of the academic community, experts and the public administration, where appropriate educational initiatives should be offered.

\section{ACKNOWLEDGEMENT}

The present scientific work is funded under Project NPI 38/2019

\section{REFERENCE LIST}

Anderloni, L. \& Vandone, D. (2011). Risk of overindebtedness and behavioural factors, In: Risk tolerance in financial decision making, Palgrave Macmillan, London, pp. 113-132.

Bianchi, J. \& Mendoza, E. (2011). Overborrowing, Financial Crises and 'Macro-Prudential' Policy? IMF Working Paper No. 11/24, [Online] Available at SSRN: https://ssrn.com/abstract=1755441. Accessed 1 Nov. 2021.

Bilyk, O., Anson, T., Khan, M., Vallée, G. (2020). Household indebtedness risks in the wake of COVID-19, Staff Analytical Note 2020-8, June 2020, [Online] Available at: 
https://www.bankofcanada.ca/2020/06/staff-analytical-note-2020-8/. Accessed 20 Oct. 2021.

Brunnermeier, M., \& Julliard, C. (2008). Money Illusion and Housing Frenzies. The Review of Financial Studies, 21(1), 135-180. Retrieved January 29, 2021, from http://www.jstor.org/stable/40056815.

Bucks, B. \& Pence, K. (2008). Do borrowers know their mortgage terms? Journal of Urban Economics, Elsevier Inc., 64(2), 218-233.

Djoudad, R. (2011). A Framework to Assess Vulnerabilities Arising from Household Indebtedness Using Microdata. IFC Bulletins chapters, in: Bank for International Settlements (ed.), Proceedings of the IFC Conference on "Initiatives to address data gaps revealed by the financial crisis", Basel, 25-26 August 2010, volume 34, 151-168.

Dynan, K. \& Kohn, D. (2007). The Rise in U.S. Household Indebtedness: Causes and Consequences, Finance and Economics Discussion Series 2007-37, Washington: Board of Governors of the Federal Reserve System.

Finocchiaro, D. et al. (2011). Household indebtedness, house prices and the macroeconomy: a review of the literature, Sveriges Riksbank Economic Review, №1, pp. 6-28.

Finocchiaro, D. et al. (2016). Macroeconomic Effects of Reducing Household Debt, Sveriges Riksbank Economic Review N2, pp. 57-88.

Gathergood, J. (2014). Self-Control, Financial Literacy and Consumer Over-Indebtedness, Journal of Economic Psychology, 107, 455-469.

Geanakoplos, J. (2010). Solving the Present Crisis and Managing the Leverage Cycle, FRBNY Economic Policy Review, pp. 101-131.

Gerardi, K., Goette, L. \& Meier, S. (2010). Financial Literacy and Subprime Mortgage Delinquency: Evidence from a Survey Matched to Administrative Data, Federal Reserve Bank of Atlanta Working Paper 201010.

Gerardi, K., Rosen, H. \& Willen, P. (2010). The impact of deregulation and financial innovation on consumers: the case of mortgage markets, Journal of Finance, American Finance Association, vol. 65, issue 1, pp. 333-360.

International Monetary Fund (2005). Household balance sheets, Global Financial Stability Report, Washington, April, 62-91.

Lorenzoni, G. (2008) Inefficient Credit Booms. The Review of Economic Studies, vol. 75, no. 3, pp. 809-833. JSTOR, www.jstor.org/stable/20185056. Accessed 28 Oct. 2021.

Lusardi, A. \& Tufano, P. (2015). Debt literacy, financial experience and overindebtedness, Journal of Pension Economics and Finance, Cambridge University Press, vol. 14(04), 332-368.

Persson, M. (2009). Household indebtedness in Sweden and implications for financial stability - the use of household-level data, in Household debt: implications for monetary policy and financial stability, BIS papers, vol. 46, 124-135.

Petrov, D., Tonkova, E., Todorova, S. (2021). EU Household Indebtedness Prior to the Covid -19 Global Pandemic Crisis. New Challenges of Economic and Business Development - 2021: Post-Crisis Economy, 13th International Scientific Conference, Proceedings, May 13 - 15, 2021, Riga, University of Latvia, pp. 309-316.

Piazzesi, M. \& Schneider, M. (2007). Inflation Illusion, Credit, and Asset Pricing, NBER Working Papers 12957, National Bureau of Economic Research, Inc.

Santoso, W. \& Sukada, M. (2009). Risk profile of households and the impact on financial stability, BIS Papers chapters, in: Bank for International Settlements (ed.), Household debt: implications for monetary policy and financial stability, volume 46, 58-74. 